12. Virolainen, K. Macro Stress Testing with a Macroeconomic Credit Risk Model. Bank of Finland [Electronic resource] / K. Virolainen // SSRN Electronic Journal. - Available at: \www/ URL: https://doi.org/10.2139/ssrn.622682

\section{ПРОБЛЕМЫ ПРОГНОЗИРОВАНИЯ БАНКРОТСТВА} НЕПРОИЗВОДСТВЕННЫХ КОМПАНИЙ

В работе выявлены возможности использования скоринговых моделей Альтмана и Олсона в целях прогноза банкротства непроизводственных компаний в горизонте операционного периода 1-4 года. Исследование раскрывает особенности применения указанных моделей в целях оценки устойчивости компаний.

Ключевые слова: модель Альтмана Z-скоринг, модель Олсона О-скоринг, непроизводственные компании, банкротство корпорации.

Ярыгина Ирина Зотовна, доктор экономических наук, профессор, кафедра мировой экономики и мировых финансов, Финансовый университет при Правительстве Российской Федерации, Москва, Российская Федеращия, e-mail: jiz4@yandex.ru.
О’Мэлли Патрик, кафедра мировой экономики и мировых финансов, Финансовый университет при Правительстве Российской Федерации, Москва, Российская Федерация,

e-mail: patrick.o-malley@ucdconnect.ie.

Яригіна Ірина Зотовна, доктор економічних наук, професор кафедра світової економіки $і$ світових фінансів, Фінансовий університет при Уряді Російської Федерацї, Москва, Російська Федерація.

О’Меллі Патрік, кафедра світової економіки $і$ світових фiнансів, Фінансовий університет при Уряді Російської Федерації, Москва, Російська Федерація.

Yarygina Irina, Financial University under the Government of the Russian Federation, Moscow, Russian Federation, e-mail: jiz4@yandex.ru.

O'Malley Patrick, Financial University under the Government of the Russian Federation, Moscow, Russian Federation,

e-mail: patrick.o-malley@ucdconnect.ie

\title{
Dohrovol'ska 0.
}

\section{ANALYSIS OF CREDIT COOPERATION IN THE CURRENT ECONOMIC SPACE}

Обгрунтовано можливі напрями розвитку кредитної кооперащії та виокремлено основні віхи становлення кредитних спілок в Україні. Досліджено тенденщї розвитку кредитних спілок $і$ визначено пріоритетні напрями іх діяльності у майбутньому. Проведено аналіз стану кредитних спілок України, акцентовано увагу на розбудову трирівневої кооперативної кредитної системи в порівнянні зі світовим досвідом.

Ключові слова: кооперація, кредит, кредитна спілка, комериійний банк, фінансова установа, кооперативний банк, фінансове забезпечення.

\section{Introduction}

In a developed society, financial services are not less important than production. The most actively develops that segment of a service, which is related to the needs of social production and consumption, as well as financial and credit services, insurance services and more. One of the participants of the financial market is a savings and credit cooperatives - credit unions, which Ukraine has always been a form of self-organizing community.

The history of credit relations in Ukraine made up on the basis of those credit relationships that existed in the Soviet Union. Transition from a planned to a market economic system in the field of credit relationships was implemented faster than in other areas of our country. The reason is that the basis of this relationship is the most mobile resource - money.

Today it is particularly important as the growing number of financial intermediaries and improving the efficiency of their activities; it is important to develop not only banks but also other financial institutions of different types, to ensure the full functioning of the financial infrastructure that will serve as the key to economic growth. Problems of credit unions are more acute in the financial crisis and the crisis of the banking system of Ukraine. All this determines the relevance and need for research on the current state and further development of credit unions.

\section{The object of research and its technological audit}

A study of possible development directions of credit cooperatives for current challenges of economic space is conducted for effective formation. Modern credit cooperatives are the two most common types: cooperative banks (mostly in Europe) and credit unions (in most parts of the world) and are credit and cooperative sector of the economies of many countries.

The proposed model for developing three-level cooperative credit system in Ukraine provides phased expansion of the market mandate for credit unions in corporate lending and the provision of financial services, creation of credit cooperatives, central and local cooperative banks and other elements of the system that are addressing the whole spectrum of problems, in particular the system of guarantees and deposit insurance system to support the financial stability of credit unions, credit bureaus, centers of information technology, service infrastructure that would ensure minimizing risk and entry of credit unions in payment systems, educational infrastructure and so on. 


\section{The aim and objectives of research}

The aim of research is scientific substantiation of possible directions of credit cooperation for current challenges of economic space.

To achieve this aim, there are following scientific research tasks:

1. Analyze the conditions of credit unions in Ukraine.

2. Identify the main factors of deceleration of credit cooperatives in Ukraine, taking into account international experience.

3. Make recommendations for the further development vector of cooperative credit system in Ukraine.

\section{Literature review}

Many famous economists and practitioners are paid attention to the study of the nature, role, task and value of credit cooperatives in the agricultural sector.

Author [1] states that credit cooperatives have different names, such as the loan company, loan office, savings and loan association, credit association, depending on the characteristics (professional and national structure, seat of the cooperative, nature of the activities, cooperative subordination). Credit cooperative is the common name for the definition of institutions, which on economic substance are the subjects (native) of credit cooperation as a phenomenon. In support of this we can quote modern scientists [2]: «Credit Unions are a form of cooperatives operating in the financial and credit sector». Definition of credit cooperatives (associations, unions) as intermediaries in the money market, which activity is based on a cooperative basis, is provided by scientists [3], because it considers these institutions in the context of the study of the nature and mechanisms of money and credit. Russian scientist [4], who studied the theory of credit and other forms of cooperation in the early twentieth century, considered credit cooperation «from two perspectives: as a form of cooperative enterprises and as a form of credit institutions». The economic encyclopedia states that credit cooperation is a subsystem of economic property relations between members of the credit union on forming a joint cooperative property and its use for financial assistance [5]. In [6] «people's banks» in nature have a dual character, as set the two opposing aims: to provide cheap credits to its members that it is inherent in the cooperative organizations and ensure their greatest dividend on share capital. A famous researcher of cooperative movement [7] identifies their most characteristic features in his works, such as:

1) lack of equity capital (or shares have a nominal nature);

2) localization - and area restriction of cooperative activities;

3) free of charge of controls;

4) unlimited liability of its members (the ban to be a member at the same time in several cooperatives);

5) discrepancy between active and passive operations.

Russian economist, teacher, lawyer, social worker [8], who studied and teach the theory and practice of cooperative movement in Europe and in the early twentieth century, highlights two fundamental principles, namely:

1) aim is not only to improve the financial condition of its members, but also to improve their morals;
2) $2 / 3$ of the net income of the company forms the so-called «indivisible capital», which is not distributed among the members, and is for development of the cooperative. However, these principles are not widely used, and defined as being offset by experience.

According to the author [9], application of the selfgovernment principle provided by the general assembly as the highest control body, where each member has one vote may be achieved confidence in the credit cooperative. According to Ukrainian researcher of credit cooperation [10] «the shared purpose of credit unions are providing cheap credit to its members». In a study of the financial mechanism of cooperation in [11] for the first time provides interpretation of non-profit cooperative organization, as a matter of «...that is a most controversial in cooperative relations».

Significant results of theoretical and methodological nature were obtained thanks to the efforts of scientists and researchers. These results significantly enriched the national economic science. However, despite the relatively large number of scientific articles on the problems of formation and development of credit cooperation, there is a need for further scientific development to identify possible areas of their development today.

\section{Materials and methods of research}

To achieve the objectives we used the following methods: analysis and synthesis, logic synthesis, analogies, comparative, monographic and graphic-analytical methods.

\section{Research results}

Development of credit cooperation in the world was started in Germany in the mid-50s of XIX century. Since in most countries credit cooperative movement entered its development in three models [12]:

1) rural credit cooperatives of $F$. Raiffeisen;

2) urban credit cooperatives of G. Schulze-Delitzsch;

3) «Offenbach» model of credit cooperation.

Financial relations in the cooperative are sufficiently transparent and understandable to the general public that attracted maximum number of its members.

In the world there are different types of financial and credit cooperatives. Features of their activities are determined by the national law of each country. In some countries, credit cooperatives provide only financial services, in others - can further implement commodity transactions, in the third - to be universal cooperatives with financial functions.

Credit cooperatives in different countries may have different names [13]:

- Credit Union is the most common name of credit cooperative in the USA, Canada, UK and many other countries;

- Volksbank and Raiffeisenbank - in Germany;

- cooperative savings and credit union - in Poland;

- Cooperative Caisses - Quebec (Canada);

- People's bank or credit cooperative - in France and many African countries.

In addition, in some countries, credit cooperatives can be found under diverse names: Credit Society, Financial Cooperative, Cooperative Savings and Loan Association, People's Bank, Cooperative Bank, Building and Loan 
Association, Poormen's Bank, Rural Base, Mutual Benefit Fund, Mutual Credit and so on [14].

Thus, modern credit cooperatives are represented by two most common types: cooperative banks (mostly in Europe) and credit unions (in most parts of the world) and are credit cooperative sector of the economies of many countries. There are more than 51 thousand credit unions, more than 3,8 thousand of cooperative banks, the number of members - 196,5 million and 56,4 million people respectively, total assets $-1,564$ billion dollars and 9,733 billion dollars respectively [6, 15].

In modern independent Ukraine credit cooperative sector of the economy began to revive in the early 1990 s in the form of credit unions. For the first 20 years of its existence, they were rather complicated way, having undergone significant changes both in legal status and in the assessment and perception of society [16].

Credit Union (CU) is a non-profit organization founded by individuals on a cooperative basis to meet the needs of its members in a reciprocal lending and providing financial services due to the combined financial contributions of the members of credit union [17]. This is one of the most attractive financial organizations to the public, which is a non-profit alternative to banks. CU activities aimed at providing credit and deposit services to its members. But there are some differences that distinguish credit unions from classical financial institutions - commercial banks (Table 1).

Also, unlike banks, to use the services of a credit union, it become a member by writing an application and pay them share and membership fee. Dimensions of membership fees depending on the decision of CU committee and may be different - from $1 \mathrm{UAH}$ to $500 \mathrm{UAH}$. Initiation fee is not returned in the case of leaving the union [18].

The scheme of credit unions is simple [19]: some members of the organization, protecting their money from inflation, place them on deposit, while others - use these funds to give credits. CU build their activities on the savings of shareholders, their equity and savings deposits, which form a fund of financial mutual assistance - source of cash loans to shareholders. All resources involved CU usually short (1 year), because few individuals invest money in a credit union for a long time. Unlike banks, credit unions don't have the concept of «client» and «owner» because all its members are both clients and owners.

Acceptance of «deposits» and provide «credits» in the cooperative are linked. Therefore, if the growing interest in placing loans and lower demand for money in the debt, receiving additional «deposits» may be suspended.

In 2015, the population of rural areas is amounted to 14396,3 thousand people, or $31,4 \%$ of the population [20]. However, $80 \%$ of agricultural producers are not able to attract credits because banks are not interested in lending. Therefore, in most rural areas of Ukraine, credit unions today are only financial institutions where agricultural producers can receive credit. However, the system of credit unions irregularly branched, the number of branches and affiliates is insufficient and the amount of available credit doesn't allow credit unions to meet the needs of agricultural producers.

In modern times credit cooperative system of Ukraine requires major changes [21]:

- in the field of legislative regulation;

- in the field of self-organization at national level;
- in the field building and development of service infrastructure;

- in the field of public relations and relations with the public;

- in the field of «cleaning» of the entire sector and a return to cooperative principles, ideas and aims.

Table 1

Comparative table of the main differences between credit unions and commercial banks

\begin{tabular}{|c|c|c|}
\hline Рагаmeter & Credit union & Commercial bank \\
\hline Institution & $\begin{array}{l}\text { Aim - to meet the financial } \\
\text { needs of its own investors } \\
\text { by providing financial as- } \\
\text { sistance to each other. } \\
\text { Owners - CU members } \\
\text { (individuals). Created by the } \\
\text { citizens in the place of resi- } \\
\text { dence or work by combining } \\
\text { their own savings without } \\
\text { for-profit and it is non-profit } \\
\text { organization }\end{array}$ & $\begin{array}{l}\text { Aim - to provide a wide range } \\
\text { of financial credit and other ser- } \\
\text { vices for unlimited contingent of } \\
\text { the clients. } \\
\text { Owners - the shareholders of } \\
\text { the bank (firms, banks, corpora- } \\
\text { tions and certain individuals). } \\
\text { Created by businessmen - a li- } \\
\text { mited group of people, who have } \\
\text { joined large amounts of capital } \\
\text { for profit, it is a commercial } \\
\text { organization }\end{array}$ \\
\hline $\begin{array}{l}\text { Manage- } \\
\text { ment }\end{array}$ & $\begin{array}{l}\text { Management - CU mem- } \\
\text { bers (each has a one vote } \\
\text { regardless of the amount of } \\
\text { membership fee); } \\
\text { general meeting of share- } \\
\text { holders, has its own mana- } \\
\text { gement, audit committee and } \\
\text { the credit committee elected } \\
\text { among shareholders }\end{array}$ & $\begin{array}{l}\text { Management - Shareholders } \\
\text { Meeting. } \\
\text { Shareholders have votes propor- } \\
\text { tional to the number of shares. } \\
\text { Banks and their branches are } \\
\text { headed by directors and mana- } \\
\text { gers, policy is formed by the } \\
\text { Board of Directors and indepen- } \\
\text { dent of the views of customers }\end{array}$ \\
\hline Result & $\begin{array}{l}\text { Incomes for the period are } \\
\text { distributed to various funds } \\
\text { that guarantee stability and } \\
\text { security of CU, the remaining } \\
\text { funds are distributed among } \\
\text { shareholders }\end{array}$ & $\begin{array}{l}\text { Incomes are distributed among } \\
\text { the shareholders by the deci- } \\
\text { sion of meeting of shareholders } \\
\text { in proportion to the invested } \\
\text { amounts }\end{array}$ \\
\hline Clients & $\begin{array}{l}\text { Individuals - CU share- } \\
\text { holders }\end{array}$ & Individuals and legal entities \\
\hline $\begin{array}{l}\text { The main } \\
\text { source } \\
\text { of credit } \\
\text { resources }\end{array}$ & Deposits of individuals & $\begin{array}{l}\text { Deposits of individuals and legal } \\
\text { entities, credits from financial } \\
\text { institutions and share capital }\end{array}$ \\
\hline Regulator & $\begin{array}{l}\text { State Commission for State } \\
\text { Regulation of Financial Ser- } \\
\text { vices Markets }\end{array}$ & $\begin{array}{l}\text { National Bank of Ukraine (heavy } \\
\text { regulation of banks) }\end{array}$ \\
\hline $\begin{array}{l}\text { Deposit } \\
\text { back guar- } \\
\text { antee }\end{array}$ & $\begin{array}{l}\text { Not guaranteed by the sta- } \\
\text { te - CU must itself create } \\
\text { reserves to compensate for } \\
\text { bad debts, do not engage in } \\
\text { risky operations }\end{array}$ & $\begin{array}{l}\text { Guaranteed by the state (the De- } \\
\text { posit Guarantee Fund) in amount } \\
\text { to } 150 \text { thousand UAH }\end{array}$ \\
\hline Publicity & $\begin{array}{l}\text { CU activities are not public. } \\
\text { The relationship between the } \\
\text { credit union and sharehol- } \\
\text { ders result from the mem- } \\
\text { bership and a non-client } \\
\text { relationship }\end{array}$ & $\begin{array}{l}\text { The bank activities are public. } \\
\text { The agreement between the bank } \\
\text { and its client is a public agree- } \\
\text { ment too }\end{array}$ \\
\hline
\end{tabular}

Credit movement in Ukraine began its origin together with the declaration of independence and now has 588 credit unions [22] (Table 2) with total assets of 2,34 billion UAH and the total number of members 821,6 thousand people (Table 3 ). 
Table 2

The number of credit institutions in the State Register of financial institutions for 2009-2015

\begin{tabular}{|l|c|c|c|c|c|c|c|}
\hline $\begin{array}{l}\text { Registration of credit } \\
\text { institutions }\end{array}$ & 2009 & 2010 & 2011 & 2012 & 2013 & 2014 & 2015 \\
\hline $\begin{array}{l}\text { Number of credit in- } \\
\text { stitutions in the end of } \\
\text { period, including }\end{array}$ & 816 & 730 & 691 & 708 & 739 & 711 & 728 \\
\hline Credit unions & 755 & 659 & 613 & 617 & 624 & 589 & 588 \\
\hline Other credit institutions & 32 & 42 & 49 & 62 & 85 & 92 & 110 \\
\hline $\begin{array}{l}\text { Legal entities of pub- } \\
\text { lic law }\end{array}$ & 29 & 29 & 29 & 29 & 30 & 30 & 30 \\
\hline
\end{tabular}

Note: compiled by the author according to [22]

Table 3

Dynamics of the major activity indicators of credit institutions at the end of the year

\begin{tabular}{|c|c|c|c|c|c|}
\hline \multirow[b]{2}{*}{ Credit unions } & \multirow[b]{2}{*}{2012} & \multirow[b]{2}{*}{2013} & \multirow[b]{2}{*}{2014} & \multicolumn{2}{|c|}{ Growth rate, \% } \\
\hline & & & & $\begin{array}{l}2013 / \\
2012\end{array}$ & $\begin{array}{l}2014 / \\
2013\end{array}$ \\
\hline $\begin{array}{l}\text { The number of registered } \\
\text { credit unions }\end{array}$ & 617 & 624 & 589 & 1,14 & $-5,6$ \\
\hline $\begin{array}{l}\text { The number of CU members } \\
\text { COP (thous. persons) }\end{array}$ & 1095,9 & 980,9 & 821,6 & $-10,5$ & $-16,2$ \\
\hline $\begin{array}{l}\text { The number of CU members, } \\
\text { which have fees on deposit } \\
\text { accounts, (thous. persons) }\end{array}$ & 44,9 & 40,3 & 31,5 & $-10,2$ & $-21,8$ \\
\hline $\begin{array}{l}\text { The number of CU members, } \\
\text { which have existing credit } \\
\text { agreements, (thous. persons) }\end{array}$ & 254,0 & 233,6 & 186,6 & $-8,0$ & $-20,1$ \\
\hline Total assets (mln. UAH) & 2656,9 & 2598,8 & 2338,7 & $-2,2$ & $-10,0$ \\
\hline Capital (mln. UAH) & 1088,7 & 1055,6 & 1048,7 & $-3,0$ & $-0,7$ \\
\hline $\begin{array}{l}\text { Credits to CU members (bal- } \\
\text { ance at the end of period) } \\
\text { (mln. UAH) }\end{array}$ & 2531,0 & 2349,1 & 1994,4 & $-7,2$ & $-15,1$ \\
\hline $\begin{array}{l}\text { Contributions from CU mem- } \\
\text { bers on deposit accounts } \\
\text { (balance at the end of period) } \\
\text { (mln. UAH) }\end{array}$ & 1287,5 & 1330,1 & 989,8 & 3,3 & $-25,6$ \\
\hline
\end{tabular}

Note: compiled by the author according to [22]

Since 2011, credit unions provide a loan in the amount of 5-10 thousand UAH (the average credit amount is more than 8 thousand UAH) usually for the purchase of household appliances and home repair.

Credit unions provide on the basis of joint work of its members belonging to one union or organization on the basis of residence in the region and so on. Therefore, there is a possibility of failure in receiving as a $\mathrm{CU}$ member the loaners, who do not meet the principle of its creation.

Meanwhile, market development of credit cooperatives in 2015 held back:

- Negative forecasts of stability of the national currency and consequently rapid outflow of deposits.

- Decline of purchasing power, lack of confidence in the stability of income and expectations of further decline in real wages.

Considering these factors, the number of credit unions for 2015 remained almost unchanged.

It should be noted that at the beginning of 2000 credit cooperative movement in Ukraine was random due to lack of regulatory component. The situation in the market of credit unions began to stabilize after the adoption of a number of regulations.

The essential feature of credit cooperation in Ukraine is that $60 \%$ of credit unions have a number of members in 1000 , the share of credit unions uniting over 50000 people is only $3 \%$ [23].

The main objectives, which involve credits by credit unions, are: needs, business objectives, construction and housing repair, agriculture and farming.

The largest share in the credit portfolio owned by credits obtained for consumer needs $(41,74 \%)$. However, it is worth noting that in recent 7 years it was decreased by $8,6 \%$ - from $50,3 \%$ in 2009 to $41,7 \%$ in 2015 [20].

Lending of agriculture and farming was significantly increased from $2,8 \%$ in 2009 to $7,6 \%$ in 2015 . Commercial lending was decreased by $14,5 \%$, while lending to the acquisition, construction and repair of housing was increased by $8,0 \%$, while the share of credits obtained in other needs was increased by $9,2 \%$ over the same period.

The share of equity of credit unions in total assets at the end of 2015 was decreased and was 9,74 million UAH. Financial performance of credit unions reflects their gradual overcoming consequences of the global financial crisis.

Performance analysis shows that one of four credit union in the year was the increase of deposit portfolio, despite the instability of the hryvnia exchange rate in this period.

The main problems that affect the overall condition of credit cooperation in Ukraine should be considered: insufficient development of credit unions both in quantity and quality; impossible to provide credits to legal entities; payable on deposit liabilities, improperly administration, violation of cooperative principles, excessive risky of lending policy, a sharp deterioration in the solvency of borrowers by depreciation of collateral [24].

Braking factors for development of credit cooperative are: imperfection of legislation; lack of real financial support from the state; improper control of credit unions; unprofessional administrative bodies on audits of unions and, in some cases, outright cover-up of illegal activities; formation of negative public opinion in the media; encouraging of borrowers do not repay credits; unwillingness of managers of a number of credit unions to implement the basic principles of cooperative credit activity and growth of inconformity of credit union activities with the principles of cooperation.

Activities of credit cooperation in the world is focused on the development of cooperative credit systems of the type «central cooperative bank $\rightarrow$ regional cooperative banks $\rightarrow$ credit cooperatives (credit unions)», because the activities of individual credit unions can't be sufficiently efficient and competitive.

Thus, the feature of US credit unions in recent decades was the merger of credit unions caused by the need to improve their competitiveness under globalization. Leagues of states are second (regional) level system of credit cooperation. Over $90 \%$ of local credit unions are the members of the League. One of important function of leagues is to monitor changes in legislation and lobbying activities. All drafted bills may be adopted by state legislatures are analyzed in terms of their potential impact on the future work of credit unions. Leagues of states are the members of Credit Union National Asso- 
ciation (CUNA), cooperative service group (CSG) and Central (USC), forming a powerful three-level system of credit cooperation in the United States. The system of credit cooperation in Canada has two independent systems of cooperative credits: English-speaking system of credit unions and French-speaking system of cooperative caisses Desjardins in Quebec [6].

Analysis of international experience shows that in the financing of small and medium businesses in the agricultural sector dominate the non-bank credit institutions. Thus, the share of agricultural cooperative credit institutions in France is $75 \%$, Germany - $44 \%$, US - $26 \%$. This is due to differences between bank and non-bank credit institutions.

In Germany there are about 2,5 thousand credit cooperatives whose members are 14,5 million people. Credit cooperatives covered almost $80 \%$ of farmers. France has the cooperative credit system of agricultural producers Credit Agricole. This system of cooperative banks serving two-thirds of the French agricultural sector and has more than 875 billion euro assets. In Austria and the Netherlands there are branched system of cooperative banks with central cooperative bank (according Raiffeizen and Rabobank). These systems cover about $40 \%$ of deposit market in the country and provide a need of agricultural sector for credits by $90 \%$.

Cooperative credit institutions are actively developed in Asia. Bank for Agriculture and Agricultural Cooperatives operates in Thailand; Indonesia has a network of rural cooperative banks that lend to farmers under government guarantees; a similar scheme has been successful in Bangladesh. Cooperative banks lend using the simplified scheme and on softer terms than commercial banks Experience of China could be very interesting and useful for Ukraine. The first credit cooperatives in China were established in 1949 as a branch of the State Agricultural Bank to combat the rural usury.

According to a survey of farmers, $61 \%$ of respondents believe they need a credit, $12 \%$ - took a bank credit, $5 \%$ - took the opportunity of lending in the credit union (though members of credit unions is $18 \%$ ). Other respondents borrow money from relatives and friends. Credits to farms and private farms are only $3 \%$ of the credit portfolio of credit unions.

Interest rates on credits and deposits in credit unions on average $10-15$ points higher than the banks: the average cost of credits in the credit union - $33 \%$ per annum.

Priorities of credit cooperatives in the post-crisis economic conditions in Ukraine, taking into account international experience, can be defined: direction of credit unions to meet the needs of the rural population and agricultural sector of country, an introduction of state lending programs of people through credit unions and compensation of a part of interest rates on credits for agricultural producers, expanding the range of services provided by credit unions, changes to legislation governing the financial activities of credit unions to ensure stable development, reduction of risk operations and growth of public confidence in credit unions [25].

The proposed model for developing three-level cooperative credit system in Ukraine provides for the phased expansion of the market mandate of credit unions in corporate lending and the provision of financial services, creation of credit cooperatives, central and local cooperative banks and other elements of the system that are addressing the whole spectrum of problems, in particular the system of guarantees and deposit insurance, system to support the financial stability of credit unions, credit bureaus, centers of information technology, service infrastructure that would ensure minimizing risk and entry of credit unions in payment systems, educational infrastructure and so on.

The defining difference of the proposed measures is that they provide a basis for further system evolution because it exists and has proven its viability for many years and at the same time give a new impetus to development of credit cooperation system, gradually bringing it to the new basis of multivariance, diversity and a stable and reliable operation.

Necessity for local cooperative banks is caused by the need to reduce the negative impact of the current credit system to ensure the development of agricultural enterprises. The main disadvantages of this system include: a complex mechanism to obtain credit from commercial bank that is inappropriate when talking about a small amount; disinterest, unwillingness and inability of a significant number of commercial banks to provide credit resources in required quantities and at a fixed time taking into account of the functioning of agricultural enterprises; weak branching or absence of branches of commercial banks in the most remote administrative areas; high cost of financial services provided to agricultural enterprises; dispersion of free financial resources of agricultural enterprises between a large number of commercial banks, resulting in a significant proportion of the funds is used to service businesses in other sectors of the economy; lack of coordination in the activities of credit unions by their associations for operational maneuver of free financial resources of credit unions.

The aim of the cooperative banks is to improve the financial security of agricultural enterprises, especially SMEs. To achieve the aim, cooperative banks have the following tasks: to assist its members in business and increase their income; carry out constant monitoring, audit and supervision of credit unions and cooperatives; align supply and demand fluctuations on the financial resources of the entire cooperative system; develop methodological and methodical support of cooperatives and credit unions with a view as the biggest consideration of the specific of agricultural enterprises; make transactions in financial markets; lobby the interests of its members to the government; improve financial and credit services for agricultural enterprises by concentrating their available financial resources; support credit unions and cooperatives; issue securities; reduce the cost of financial services to its members.

It should be emphasized that an important element of sustainable development of credit unions in Ukraine is functioning of credit bureau. The feasibility of introducing mandatory membership of all credit unions in Ukraine in the credit bureaus will allow to access all market participants to correct data on the state of lending in Ukraine and will protect credit unions from subprime borrowers and reduce the number of troubled, delinquent and nonperforming credits.

Therefore, it should be noted that in Ukraine, despite the negative impact of the crisis in the economic area, most credit unions continue to work consistently, on time paying for all obligations, increasing lending to the rural population. 
The priorities of credit cooperatives in Ukraine should be: - Creation of credit unions within rural areas.

- Access of credit unions to cheap funds on terms of repayment, to their use as sources of credit to members of credit unions.

- Renewal of the state programs of compensation of interest rates on short-term and medium-term credits of credit unions obtained by agriculture and farming. - Expanding the range of services provided by credit unions and the introduction of licensing of certain services.

- Stabilization of the market of credit unions by reducing the risk of transactions.

- Introduction to the provisions of the Law of Ukraine «On the State Deposit Guarantee Fund for the members of credit unions to deposit accounts».

- Reduction of the risk of lending operations through mandatory membership of all credit unions of Ukraine in the credit bureaus; creating a national database of credit histories.

- Reduction of expenses related to impairment losses on non-performing credits is due to possible changes in the requirements for the formation of reserve capital of credit union.

Recently, in developed countries, the trend towards greater universalization of credit unions is observed. In particular, they provide brokerage services for securities transactions, issue the credit cards and offer advice on investment and business. The problem of the potential of Credit Unions in Ukraine and prospects of their development, based on the acquisition of international experience, is important and necessary.

Credit cooperative movement in the developed countries has established itself as the most efficient model of financial relations and as a guarantee of democratic society. In countries such as the UK, Austria and Poland, credit unions are important strategic partners and active clients of the banks. Development of credit cooperation in these countries contributed to weakening the monopoly of financial intermediaries and effective economic selfdefense through self-dependence by financial services [6].

Insurance are necessary to improve the financial stability of credit unions (credit unions don't form a statutory fund, because insurance would have a solvency of financial institutions).

The experience of the Polish system of savings and credit banks SKOK shows that logical and effective way of meeting the needs of credit unions in insurance services is creating its own mutual insurance associations (MIA) of cooperative credit system of Ukraine. MIA founders and owners can be credit unions, represented by regional associations and the members of credit unions - individuals and (in the future) legal entities. The insurance agency may be founded by association of credit unions in the form of commercial structure and cooperative, whose members would be credit unions and associations, elements of supporting infrastructure and individual members. Exclusive MIA work with the system of credit cooperation is typical for countries such as the USA, Ireland and Hungary [3].

The cooperative form of insurance institutions of credit cooperative system has significant advantages because involves each credit union to management and control.

Equally important issue in credit unions is their legal forms. In contrast to the Ukrainian credit unions,
US credit unions have the right to choose on the legal forms of consumer lending, expanding its capabilities through features that belong exclusively to commercial establishments. This is a demtualization - many-stepped process that involves a number of transitional forms. Under US law there is a chain of credit unions: credit union - the mutual savings bank - equity bank or finance company. The best example of demtualization is the conversion of a credit union «Sacred Heart» from South Carolina to mutual savings bank, transformation of Pacific trust credit union in a mutual savings bank, which became the largest savings bank in America with assets of 228 million dollars [10].

Therefore, demtualization is a stage through which credit unions have the right (if allow capital, assets of credit unions) for expansion of activities. Of course, the transformation of credit unions should take place with the consent of its members. This process undoubtedly contributed to the development of a credit movement and the economy. Right for transformation of credit unions contributes to their future prosperity, because it creates incentives for growth of capital, assets, liquidity and profitability of credit unions. So, demtualization is an element to ensure the effectiveness of economic activity of credit unions [2].

To create and build of cooperative banking system in Ukraine it should carry out the following steps:

1. Providing legal and regulatory prerequisites for creating a three-level cooperative banking system. In order to create and develop cooperative institutions at all levels of cooperative banking system it is necessary to prepare a draft of amendments to the Law of Ukraine «On Financial Services and State Regulation of Financial Markets», «On banks and banking activity», «On agricultural cooperation».

2. Creation and support of the development of institutions at the first level of cooperative banking system. It provides support of credit unions, expansion of their range of services and creation of credit cooperatives. It is necessary to prepare a draft of amendments to the Law of Ukraine «On credit unions», «On State Support of Agriculture of Ukraine», «Tax Code of Ukraine» and on the state budget of Ukraine for the year.

3. Creation of local cooperative banks - institutions of the second level of cooperative banking system. It aims to take appropriate amendments to the current legislation, including setting standards to reduce the number of founders of the local cooperative bank and expanding the territorial principle; determination that the founders of the local cooperative bank can credit unions, credit cooperatives, their associations, legal entities; creation of favorable conditions for the phased introduction of share capital within 3-5 years; creation of the procedure for appropriate supervision of cooperative banks.

4. Creation of a central cooperative bank of Ukraine. This includes providing relevant legal and economic conditions.

\section{SWOT analysis of research results}

Potential internal strengths:

- Pursuit of perfection of credit technology.

- Full competence in key areas.

- Available financial resources.

- Readiness to benefit from the favorable situation on the market, namely the demand from the credit market, which is growing.

- Willingness of management to change and innovation. 
Potential internal weaknesses:

- Obsolete software.

- Decrease in profitability due to problem credits.

- A weak control of strategy performance.

Potential external opportunities:

- Access to new markets of credit cooperation and ability to serve additional customer groups.

- Receipt of investment due to the high attractiveness of the credit industry.

- Possibility of rapid development due to the sharp increase in market demand.

- Promoting monopoly weakening of financial intermediaries.

Potential external threats:

- Instability of government policies or adverse government policies or local authorities.

- Lack of legal and economic preconditions.

- Possibility of new competition with more cheap resources.

- Constant rise in prices and reduce the purchasing power of the population.

- Inflation and the fall of hryvnia.

\section{Conclusions}

1. Based on the research it is determined that credit unions have legal, economic and social status in comparison with other economic entities. The most significant features of credit unions are, firstly, their cooperative nature, that is, their nature is a cooperative - an association of persons with a specific purpose. Secondly, it is a credit (financial) institution whose main activity is to provide credits.

2. The aim of creation and activities is mutual lending at the value for members of the association that determines the non-profit status institutions, which fixed by the norms of legislation of our country. The fundamental principles of credit unions are: voluntary freedom of entry and exit from the credit union; equality of the member of credit union; autonomy; publicity; economic participation of members in the union capital. It is noted that: absence of legal approval of the principles of economic trends in the credit union for cooperative organizations established by worldwide cooperative organizations and justified by historical experience needs urgent solution to increase the level of economic interest and responsibility of union members in its development.

3. Analysis of the national system of credit cooperation gives reason to believe that the principle of cooperation among cooperatives is not fully used. This principle is essential for building an integrated system of credit cooperatives in Ukraine and promotion of credit unions among the population, including the creation of a cooperative bank, self-regulating organization, common deposit insurance and information security.

\section{References}

1. Olenchyk, A. Ya. Kredytni spilky v Ukraini: osnovni zasady diialnosti [Text]: Tutorial / ed. by A. Ya. Olenchyk. - Kyiv: UIRFR, 2005. - 652 p.

2. Slavova, N. O. Kredytni spilky: poniattia, klasyfikatsiia, zahalna kharakterystyka [Text] / N. O. Slavova // Visnyk hospodarskoho sudochynstva. - 2007. - № 5. - P. 147-150.

3. Tereshchenko, H. M. Perspektyvy rozvytku kredytnykh spilok v Ukraini [Text] / H. M. Tereshchenko // Finansy Ukrainy. 2009. - № 5. - P. 87-94.
4. Antsiferov, A. N. Kooperativnii kredit i kooperativnye banki [Text] / A. N. Antsiferov. - Praga, 1922. - 115 p.

5. Palii, V. M. Kredytni spilky na suchasnomu etapi stanovyshcha ta rozvytku [Text]: Manual for Credit Unions / ed. by V. M. Paliia. - Kyiv, 2004. - 193 p.

6. Martos, B. Teoriia kooperatsii [Text] / B. Martos. - Podiebrady: Vydavnyche Tovarystvo pry Ukrainskii Hospodarskii akademii v Ch.S.R., 1923. - 246 p.

7. Nehrebetska, L. A. Kredytni spilky yak orhanizatsii finansovoi vzaiemodopomohy [Text] / L. A. Nehrebetska // Rehionalna ekonomika. - 1999. - № 2. - P. 121-126.

8. Pashko, I. Nuzhno trebovaniia k kreditnym soiuzam privodit' primerno do bankovskogo urovnia [Electronic resource] / I. Pashko // Informatsiinyi portal «Pro kredytni spilky: ofitsiino ta trishky bilshe...» (UkrKS.Info). - 12.08.2015. - Available at: \www/URL: http://ukrks.info/statenews/yhor-pashko-nuzhno-trebovanyya-k-kredytnyim-soyuzam-pryvodyt-prymernodo-bankovskoho-urovnya.html

9. Dadashev, B. A. Kredytni spilky v Ukraini [Text]: Tutoria / B. A. Dadashev, O. I. Hrytsenko. - Sumy: Ukrainian Academy of Banking of the National Bank of Ukraine, 2011. - 196 p.

10. Honcharenko, V. V. Kredytna kooperatsiia: Formy ekonomichnoi samodopomohy silskoho i miskoho naselennia u sviti ta v Ukraini (teoriia, metodolohiia, praktyka) [Text] / V. V. Honcharenko. - Kyiv: Hlobus, 1998. - 153 p.

11. Kozynets, P. Kredytna kooperatsiia: chy potribna vona sohodni Ukraini? [Electronic resource] / P. Kozynets // Dopovid prezydenta NAKSU na Druhykh vseukrainskykh hromadskykh slukhanniakh «Ukraina naperedodni vsesvitnoho roku kooperatyviv». - Kyiv, 2011. - Available at: \www/URL: http://www.coop-union.org.ua/wp-content/uploads/DopovidSluhannya_Kozinetc.pdf

12. Shyshuta, O. Yu. Stanovlennia silskoi kredytnoi kooperatsii v Ukraini v konteksti istorychnoho dosvidu [Text] / O. Yu. Shyshuta // Ekonomika. Finansy. Pravo. - 2001. - № 9. - P. 9-12.

13. Borodaievskyi, S. V. Teoriia i praktyka kooperatyvnoho kredytu [Text] / S. V. Borodaievskyi. - Podiebrady: Vydavnyche Tovarystvo pry Ukrainskii Hospodarskii akademii v Ch.S.R., 1925. - 380 p.

14. Slaviuk, R. A. Kooperatyvni kredytni ustanovy u finansovomu zabezpechenni rozvytku ahrarnoho biznesu [Text] / R. A. Slaviuk // Finansy Ukrainy. - 2000. - № 2. - P. 96-103.

15. Pro zatverdzhennia Metodychnykh rekomendatsii shchodo zdiisnennia diialnosti kredytnoiu spilkoiu cherez vidokremleni pidrozdily [Electronic resource]: Order of the State Commission for Regulation of Financial Services Markets of Ukraine from 30.12.2005 № 5237. - Available at: \www/URL: http:// ua-info.biz/legal/baseht/ua-dmpqzr.htm

16. Pro skhvalennia Kontseptsii rozvytku systemy kredytnoi kooperatsii [Electronic resource]: Order of the Cabinet of Ministers of Ukraine from 07.06.2006 № 321-p. - Available at: \www/ URL: http://zakon5.rada.gov.ua/laws/show/321-2006-\%D1\%80

17. Pro kredytni spilky [Electronic resource]: Law of Ukraine from 20.12.2001 № 2908-III. - Available at: \www/URL: http://zakon0.rada.gov.ua/laws/show/2908-14

18. National Association of Credit Unions of Ukraine [Electronic resource]. - Available at: \www/URL: http://www.unascu. org.ua/

19. Pro zatverdzhennia Polozhennia pro reiestratsiiu kredytnykh spilok [Electronic resource]: Order of the State Commission for Regulation of Financial Services Markets of Ukraine from 11.11.2003 № 115. - Available at: \www/URL: http://zakon5. rada.gov.ua/laws/show/z1085-03

20. Richni zvity pro diialnist Natsionalnoi komisii, shcho zdiisniuie derzhavne rehuliuvannia u sferi rynkiv finansovykh posluh, za 2012-2014 roky [Electronic resource] // State Commission for Regulation of Financial Services Markets of Ukraine. Available at: \www/URL: http://nfp.gov.ua/content/rzvitinackomfinposlug.html 
21. Rudaia, M. I. Osnovni zasady optymizatsii derzhavnoho rehuliuvannia diialnosti kredytnykh spilok [Text] / M. I. Rudaia // Zbirnyk naukovykh prats Natsionalnoho universytetu derzhavnoi podatkovoi sluzhby Ukrainy. - 2012. - № 2. - P. 205-215.

22. Ohliad rynkiv finansovykh posluh ta pidsumky diialnosti nebankivskykh finansovykh ustanov, derzhavne rehuliuvannia ta nahliad za diialnistiu yakykh zdiisniuietsia Derzhkfinposluh, za 2015 rik [Electronic resource] // State Commission for Regulation of Financial Services Markets of Ukraine. - Available at: \www/URL: http://nfp.gov.ua/

23. Richni zvity Derzhavnoi komisii z rehuliuvannia rynkiv finansovykh posluh za 2003-2010 roky [Electronic resource] // State Commission for Regulation of Financial Services Markets of Ukraine. - Available at: \www/URL: http://nfp.gov.ua/ content/rzviti-nackomfinposlug.html

24. Biliachenko, O. L. Osoblyvosti kontroliu dokhodiv kredytnykh spilok v Ukraini [Text] / O. L. Biliachenko, V. S. Zdrenyk // Finansovyi prostir. - 2015. - № 2 (18). - P. 153-159.

25. Pro Natsionalnu komisiiu, shcho zdiisniuie derzhavne rehuliuvannia u sferi rynkiv finansovykh posluh [Electronic resource]: Decree of the President of Ukraine from 23.11.2011 № 1070/2011. - Available at: \www/URL: http://zakon5.rada. gov.ua/laws/show/1070/2011

\section{АНАЛИЗ КРЕДИТНОЙ КООПЕРАЦИИ В СУЩЕСТВУЮЩЕМ} ЭКОНОМИЧЕСКОМ ПРОСТРАНСТВЕ

Обосновано возможные направления развития кредитной кооперации и выделены основные вехи становления кредитных союзов в Украине. Исследованы тенденции развития кредитных союзов и определены приоритетные направления их деятельности в будущем. Проведен анализ состояния кредитных союзов Украины, акцентировано внимание на развитие трехуровневой кооперативной кредитной системы в сравнении с мировым опытом

ключевые слова: кооперация, кредит, кредитный союз, коммерческий банк, финансовое учреждение, кооперативный банк, финансовое обеспечение.

Добровольська Олена Володимирівна, кандидат економічних наук, дочент, кафедра фінансів та банківської справи, Дніпропетровський державний аграрно-економічний університет, Україна, e-mail: Dev-privat@mail.ru.

\section{-}

Добровольская Елена Владимировна, кандидат экономических наук, доцент, кафедра финансов и банковского дела, Днепропетровский государственный аграрно-экономический университет, Украина.

Dobrovol'ska Olena, Dnipropetrovsk State Agrarian and Economic University, Ukraine, e-mail: Dev-privat@mail.ru 